\title{
Effects of Labour Disputes on Quality of Education in Public Secondary Schools in Mvita Constituency, Mombasa County, Kenya
}

\author{
Irene Ruguru Ngotho' ${ }^{1}$, Dr. Daniel Mange², Dr. Felix Kiruthu ${ }^{3}$, \\ ${ }^{1}$ Correspondent Author, Department of Public Policy and Administration, Kenyatta \\ University, Kenya \\ ${ }^{2}$ Department of Educational Management, Policy and Curriculum Studies, Kenyatta \\ University, Kenya \\ ${ }^{3}$ Department of Public Policy and Administration, Kenyatta University, Kenya
}

\begin{abstract}
Education has always been an important asset and is regarded as a key human development index; as a result various states and governments globally spend a large share of their budget on education sector as part of their strategy to achieve the Millennium Development Goals of education for all. Access to schools has improved rapidly throughout the developing world since 1990, but learning outcomes have lagged behind. Despite the fact that it is desirable to avoid a trade-off between quantity and quality, poorly managed education systems and constant labour disputes have undermined improvement in learning outcomes. The study sought to establish the effects of labour disputes on quality of education in public secondary schools. The objectives of the study are to; examine the causes of labour disputes between Teachers Service Commission and Teachers Union, to investigate the nature of conflicts between TSC and KNUT/KUPPET, to analyse the effect of labour disputes on academic Performance in public secondary schools within Mvita Constituency. The study employed the Bargaining Theory and Conflict Theory. Descriptive research design was used; study population is made up of 10,320 and a sample of 942 Students, Parents, Teachers, TSC and KNUT/KUPPET officials obtained by use of stratified sampling to cater for each classification of respondents. Data were collected through questionnaires, and interview schedules. Descriptive statistics were analysed by use of frequencies, percentages, means and standard deviations with the help of SPSS programme. On the other hand, inferential statistics are in form of both Pearson's correlation coefficient and multiple regression with the help of Correlation models. The study found that: there are conflicting interests between Teachers Service Commission and Teachers Unions. Major causes of these conflicts are salaries, poor working environment, low motivation for teachers, mishandling of teachers grievances and promotions; disputes affect school performances because at such times teachers stay away from schools and students stay at home. This leads to poor coverage of the syllabus, when schools open the workload is so high that teachers cannot cover everything forcing students to sit for examination without learning some subjects; disputes in schools take various forms such as strikes, confrontations on teacher's rights, picketing and go-slows. When a solution is not found through collective agreement, teacher's desert schools which end up closed until the disputes are resolved. Lastly conflicts, disruption of school hours and strikes moderately affect the quality of education. The relationship observed is positively strong although statistically insignificant.
\end{abstract}

Key Words: Labour Disputes, Secondary Education, Quality of Education, Public Schools, Mvita Constituency

DOI: 10.7176/ijcab.v3iII.21, URN urn:nbn:de:0000ijcab.v3iII.211

Cite this Article: 
Ngotho, I., Kiruthu, F., \& Mange, D. (2019). Effects of Labour Disputes on Quality of Education in Public Secondary Schools in Mvita Constituency, Mombasa County. International Journal of Current Aspects, 3(II), 243-259. http://journals.ijcab.org/journals/index.php/ijcab/article/view/21

\section{INTRODUCTION}

Universal education is one of the principal concerns of government around the world. In 1948, the United Nations Declaration of Human Rights proclaimed that education; especially elementary education was a fundamental human right (United Nations Educational, Scientific and Cultural Organization, 2002). Every person has a claim to basic level of knowledge regardless of his or her social, political or economic status. After decolonization occurred, education moved to the top of nation's post-independence development agendas, especially those belonging to the African continent (United Nation Agency for international Development, 2009). Education has always been an important asset and is regarded as a key human development index, as a result various states and governments globally spend a large share of their budget on education sector as part of their strategy to achieve the millennium development goal of education for all (World Bank, 2006). Access to schools has improved rapidly throughout the developing world since 1990, but learning outcomes have lagged behind. Despite the fact that it is desirable to avoid a trade-off between quantity and quality, poorly managed education systems and constant trade disputes have undermined improvement in learning outcomes (Kitunga, 2009).

Teachers' industrial action is a prevalent feature of public education systems across the globe; during the past few years teacher strikes have been observed in countries as diverse as Argentina, Brazil, Canada, Chile, China, Colombia, France, Germany, India, Israel, Italy, Lebanon, Mexico, Russia, Spain and the United States (Kagolo, 2014). A shared belief among policymakers across several of these countries is that teachers' strikes are detrimental to student learning due to their negative effect on instructional time (Baker 2013). The presence of unions, collective bargaining and labor strikes in Argentina can be traced back to the early years of the 20th century, except for the years during which the country was subject to military dictatorships (Confederacion de Educadores Argentinos, 2009). Following the reinstatement of democracy in 1983, industrial action quickly regained its status as a pervasive feature of the Argentine labor market. Public sector teachers have been the most active social protesters in the country, and current estimates suggest that they make up approximately 35 percent of all labor strikes (Chiappe, 2011).

Strike activity was more prevalent amongst South African teachers in 2007 compared with teachers in fourteen other South Eastern African states (Picho, 2014). Estimates from SACMEQ III data set indicate that South African teachers were absent for an average of 11.7 days in the year 2007 due to teacher strikes compared with the regional average for other countries of 0.16 days. The second highest occurrence of teachers strike activity was in Zimbabwe, where teachers were absent for about two days (Lumuli, 2016). A recent assessment of the minimum international labor standards which should apply to teachers as to any other category of workers, found that there is a widespread adherence to the two fundamental labor standards on freedom of association and the right to organize adopted by the ILO with some notable gaps among Arab States and in Asia (Moulton, 2011). The picture is much less positive when it comes to ratifying, and by extension adopting legislation and functioning mechanisms to apply laws on collective bargaining generally and labor relations specifically in public services, where the largest number of teachers work (Juma, 2011).Few countries have ratified these standards, with the exception of countries in Western Europe and, to a lesser extent, Latin America; no countries in Asia or Arab countries have done so 
(Rose, 2007). In Hungary, social dialogue and negotiations between the government and teachers' organizations take place within the framework of a national tripartite body responsible for trying to reconcile tripartite (government, employer, trade union) interests on a broad range of macro-economic and labor policies (Adler, 2008).

The role of Education in Kenya as an overt secret ingredient in the openly shared recipe for attaining Vision 2030 cannot be ignored. The Sessional paper No. 1 of 2005: a policy Framework for Education, Training and Research explains that teachers are an important input in the Education system (Republic of Kenya, 2005). Given that teachers play a vital role in the development of the needed human resource for developing Kenya into a socially, politically and economically developed country in the globally competitive arena through the Vision 2030 platform, there is thus an inherent need to develop, manage and enhance professional behavior amongst teachers who are tasked with developing the needed human resource (Ndlovu, Phiri and Mutale, 2014). KNUT and KUPPET have accomplished tremendous goals for its members on matters relating to teachers welfare and advocacy for high quality standards of education from the government (Lumuli, 2016). The goals have been achieved with the help of major partners who have supported education programmes focusing on teacher's professionalism and empowerment, job satisfaction, children's rights, TSC engagement initiatives and participation in drafting of education bills (Nyambala, 2001). Although significant progress has been realized in teachers professionalism management over the years, the quality of education in Kenya has been hampered by limited skills (Ibrahim, 2007), large class sizes, inadequate teachers' training and facilities, poor remuneration compared to other economy sectors, among others, resulting in frequent calls for strike while negotiating for higher salaries, (Ibrahim, 2007). According to Nabibya (2013), teachers unions have directly and indirectly organized teachers strikes that have led to loss of time hence limited coverage and disruption of general activities. Mvita constituency in Mombasa County has performed dismally in national examinations as compared to other constituencies around the country. With strikes happening in Kenya every academic year, it is important to establish the effect of the strikes on academic performance in the constituency.

\section{STATEMENT OF THE PROBLEM}

In academic settings, labour dispute is inevitable for the fact that there are different interests pursued by different parties/unions and the consensus of opinion regarding rules governing the school seldom exists among the management, academic staff and non-academic staff. There is potential for disputes in most decisions which the management makes. Coping efficiently and effectively with potential and identified dispute is possibly one of the most important aspects of the management position in any organization. For many years, education quality in public secondary schools has been affected because of consistent trade disputes that has led to teachers downing their tools almost every year leading to closure of schools and loss of many school hours especially when schools are about to open or during periods of National Examinations (Alan, 2007). The previous Kenyan studies investigated on the causes of teachers' labour disputes found out that some of the causes were poor remuneration, lack of adherence to collective bargaining agreement, delays in job group promotions and poor working conditions (Mugho, 2017; Onyango, 2012 \& Gathoronjo, 2008). However, these studies did not address effects of the said disputes on the quality of education in public secondary schools. It was therefore important to find out the effect that the said labor disputes have on the quality of education in Kenya and particularly in Mvita Constituency, Mombasa County. 


\section{RESEARCH OBJECTIVES}

i. To examine causes of labor disputes between Teachers Service Commission and Teachers Unions.

ii. To investigate the nature of conflicts between TSC and KNUT/KUPPET.

iii. To examine the effect of labor disputes on quality of education in public secondary school within Mvita Constituency, Mombasa County.

\section{THEORETICAL FRAMEWORK}

This study was based on two theories, that is; bargaining theory and conflict theory. The two theories helped the researcher in understanding conflict resolutions in relation to labour disputes between Teachers Service Commission and Teachers Unions.

\subsection{Bargaining Theory}

This theory outlines the behavioral underpinnings of negotiators for using strategic information in disputes resolutions as stated by (Klandermans, 1984). During bargaining, parties can adjust their claims, reframe their grievances, be more patient or otherwise alter their input in the bargaining process (Centola \& Macy, 2007). Due to differences in behaviours, negotiators and workers can imitate each other. For example, when employees learn a wage claim rewarded elsewhere, they could become eager to make the same demand otherwise the negotiator for employees or for the employer could decide to a unilateral adjustment of strategy. In other instances the employer can be well informed about the strength of a union and its resources for mobilization with an anticipation of an industrial action (Addison \& Teixeira, 2009), he can reward the claim without conflict. Furthermore, both negotiators for employees and for the employer could decide to a mutual adjustment of strategy. Through the theory it has been realized that, better information about the causes of a conflict and the interests/strength of the other party could inspire both parties to find a common solution. Clearly, simple imitation is a catalyst of conflict, while unilateral and mutual adjustment could lead to appeasement and the prevention of industrial conflict. A theoretical explanation for the spread of industrial conflict must incorporate such conditions.

\subsection{Conflict Theory}

Conflict theory is synonymous with the pluralist or the pluralistic frame of reference which is also credited to Alan Fox who proposed it in 1966, (Fryer, 2011). Conflict theory views the organisation as combination of sectional groups with different values, interests and objectives. Thus, employees have different values and aspirations from those of management, and these values and aspirations are always in conflict with those of management. Conflict theorists argue that conflict is inevitable, rational, functional and normal situation in organizations, which is resolved through compromise and agreement or collective bargaining. Conflict may have either a positive or a negative effect on organizational performance, depending on the nature of the conflict and how it is managed (Armstrong, 2009). For every organization, an optimal level of conflict exists which is considered highly functional as it helps to generate good performance. When the conflict level is too high that is dysfunctional, performance suffers. Consequently, innovation and change are difficult, and the organization may have difficulty in adopting to change in its environment. Second, the organization's very performance is also threatened if the conflict is too low. On the other hand, if the conflict levels become too high and too low, the result is chaotic in an organization and also threaten its survival (Beardwell and Claydon, 2007). 
If conflict is in the education system is well-managed, it adds to innovation and productivity (Murthy, 2006). Briscoe and Schuler (2004) offered procedures for turning dysfunctional conflict into functional conflict, stating that too many organizations tend to take a win-lose, competitive approach to conflict or-at-worst avoid conflict altogether. Such a negative view of conflict ensures that a group is ineffective and the activity within it becomes destructive. However, a positive view of conflict leads to a win-win solution. Within a group, the member can take any one of the three views of conflict: dysfunctional conflict, conflict avoidance and functional conflict. Conflicts are a clear indication that something is wrong within the organization and that sound principles are not being applied in managing the activities of the organization. Browarys and Price (2008) based their approaches on the principles of authority and unity of command to eliminate conflict. They believed that conflicts could be eliminated or avoided by recruiting the right people, carefully specifying job descriptions, structuring the organization in such a way as to establish a clear chain of command and establishing clear rules and procedures to meet various contingencies. Conflict theorists view trade unions as legitimate challenges to managerial rule or prerogatives and emphasize competition and collaboration. This view recognizes trade unions as legitimate representative organizations which enable groups of employees to influence management decisions (Jones, 2012). Jones further states that the pluralist perspective would seem to be much more relevant than the unitary perspective in the analysis of industrial relations in many large unionized organizations and congruent with developments in contemporary society. The study applied conflict theory as it emphasizes the need for managers or state functionaries to acknowledge the importance of trade unions like KNUT/KUPPET in the advocacy of teacher's grievances and settling of disputes to school operations are not disrupted by strikes or other form of industrial actions.

\section{CONCEPTUAL FRAMEWORK}

Onen and Oso (2009) note that a conceptual framework is a diagrammatic presentation of a theory and that it is presented as a model when research variables and the relationship between them are translated into a visual picture to illustrate the interconnections between the independent, intervening and dependent variables. The conceptual framework is therefore a scheme of concepts which the study used in order to achieve the set objectives. The conceptual framework highlights the relationship between the independent and dependent variables of the study. The independent variables in this study were the nature of labour disputes and the causes of disputes. As shown in Figure 1, labour disputes can be in the form of strikes or go slows. The causes of labour disputes could include low wages and salaries, lack of technical support, or breaching of an agreement by the government.

In this study conflicts between the TSC and teachers means factors that lead to labour disputes between teachers and their employer teacher's services commission. The study argues that labour disputes are caused by three sets of factors: low wages and salaries, lack of technical support, or breach of agreement by the government. When any or a combination of these three factors happen, teachers respond by going on strike or staging go slows. Failure to address the strikes and go slows may negatively affect the academic performance of students due to the wasted time. Strikes and go slows could also lead to high rates of school dropout as teachers are unavailable to supervise students and maintain discipline. This study therefore sought to highlight major issues that have led to labor disputes. Effects on academic performance were used to highlight deviations on students' scores as a result of time lost during the disputes. Lastly, labour disputes happen when disagreement or conflicts happen between employees and employers. 


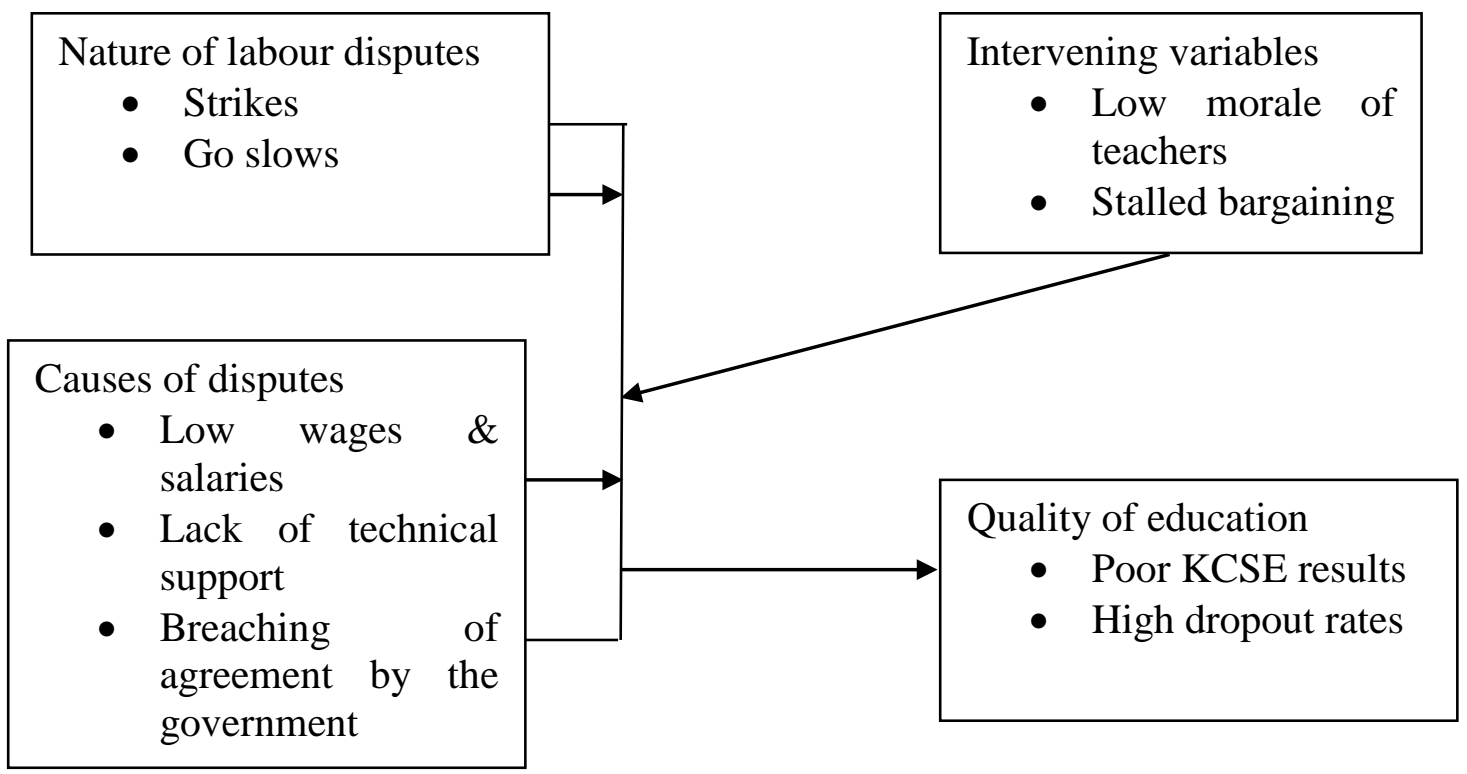

\section{Independent variables}

\section{Dependent variable}

Figure 1: Conceptual Framework

\section{RESEARCH METHODOLOGY}

The study adopted a descriptive research design because the goal of the research was to understand a particular social situation, event, and role and group interaction (Labaree \& Scimeca, 2016). The research design was appropriate because, through the interactions it was easy to get a deeper meaning and comprehensive coverage of the study. Figure 3.1 illustrates a descriptive research design used in the study. The study was carried out in public secondary schools in Mvita Constituency of Mombasa County. The study location was selected because of all Public Secondary Schools within the constituency are not far apart from each other making it cost effective. Further, it was easy to access the relevant government institutions and trade unions offices which are located within the Constituency which previously served as the headquarters for the former Coast Province. Finally, collection of data due to proximity to my workplace was easier. The independent variables of the study are nature of labour disputes and causes of disputes. Nature of disputes were measured by strikes and go slows while the causes of disputes were measured by factors such as low wages and salaries, lack of technical support and breaching of agreement with the government. These factors are expected to have a negative impact on teacher's morale and work performance which eventually influences students' academic performance which is the dependent variable of the study.

The target population of this study comprised of 20 TSC officials; 30 KNUT/KUPPET officials and students from public secondary schools in Mvita Constituency, Parents and Teachers. Stratified random sampling technique was adopted and the target population may be divided into strata's. According to Mugenda and Mugenda (2006), stratified random sampling involved selecting subjects in such a way that the existing sub-groups in the population are more or less reproduced in the sample. The study used a sample of 947 comprising of; TSC officials, County administrators, students, parents and teachers a sum of $10 \%$ of each cluster of population as illustrated in the table below. According to Mugenda and Mugenda (2006) a sample size between $10 \%$ and $30 \%$ is considered a sufficient sample size. The questionnaires capturing information relating to quality of education and impact of teachers strike cultural were issued, filled then returned for analysis. The questionnaires were 
preferred because: questionnaires acts as a source of reference hence were used at a later time to prove that the research was carried out, a large number of sampled population was realized within a short time and it is a cheaper way of conducting a research and anonymity of the respondents filling the questionnaire helped them be honest. The questionnaire had four sections. The first section had captured background information of the study respondents. The second section contained information on the effects of disputes on academic performance. The third section captured data on the various causes of conflicts between TSC and teachers unions and the fourth section captured the nature of disputes between Teachers Service Commission and KNUT/KUPPET.

Questionnaires were framed comprehensively enough to ensure that it collects all information needed to address the objectives of the research. After collection of the data, the researcher coded the items and edited them to detect errors and omissions for maximum accuracy and precision. The analysis generated both quantitative and qualitative data that was analyzed using descriptive and inferential statistics with the aid of Statistical Package for Social Sciences (SPSS). Descriptive statistics included frequencies, percentages, means and standard deviations. On the other hand, inferential statistics was done in form of multiple regressions. Correlation facilitated drawing of inferences on relationship between each of the independent variables (causes of disputes, implication of disputes, policies to improve education standards and policies to solve disputes in the education sector income level) and the dependent variable (quality of education in schools). Analysis of qualitative data was facilitated by organizing the data in tables that were sorted by respondent, question, and other characteristics. Multiple regression enabled assessment of the implication of the independent variables on education standards in public secondary schools as a whole. The following regression model was used in analysis at (5\% significance level): $Y=\beta_{0}+\beta_{1} X_{1}+\beta_{2} X_{2}+\beta_{3} X_{3}$ $+\varepsilon$. Where: Alpha $(\alpha)$ is the constant, $\left.\beta_{0}, \beta_{1}, \beta_{2}, \beta_{3}, \beta_{4}\right)$ are coefficients, $Y=$ Education standards, $X_{1}=$ Causes of labour disputes, $X_{2}=$ Academic performance, $X 3=$ Nature of disputes, $\varepsilon=$ error term. The regression coefficient ' $\beta_{0}$ ' is the Y intercept; while $\beta_{1}, \beta_{2}, \beta_{3}$, are the net change in $Y$ for each change of $X_{1}, X_{2}$, and $X_{3}$. The error term is a random variable with a mean of zero, which captured those variables that cannot be quantified.

\section{RESEARCH FINDINGS}

\subsection{Causes of Labour Disputes between Teachers Service Commission and Teachers Unions}

The first objective of the study was to examine the causes of labour disputes between Teachers Service Commission and Teachers Unions. To address this objective, the study respondents were asked to indicate their level of agreement or disagreement on various causes of disputes between TSC and Teachers unions. A 5- point likert scale was used. The higher mean scores on the scale illustrated that most of the respondents agreed with the statements in the table while the lowest mean scores on the scale illustrated that majority of the respondents disagreed with the statements in the table. Table 1 illustrates descriptive statistics analysis (means, standard deviations and variance) obtained from the results.

Table 1: TSC and Teachers Union

\begin{tabular}{|l|l|l|l|l|l|l|}
\hline Statement & Min & Max & Mean & \multicolumn{2}{|c|}{ Std. Dev. } & \multicolumn{2}{|c|}{ Variance } \\
\cline { 2 - 7 } & Stat. & Stat. & Statistic & Std. Error & Stat. & Stat. \\
\hline $\begin{array}{l}\text { Salary is the major cause of } \\
\text { disputes }\end{array}$ & 10 & 14 & 12.00 & .707 & 1.581 & 2.500 \\
\hline $\begin{array}{l}\text { The working environment is } \\
\text { not good for Teachers. }\end{array}$ & 5 & 11 & 8.00 & 1.000 & 2.236 & 5.000 \\
\hline \hline
\end{tabular}




\begin{tabular}{|l|l|l|l|l|l|l|}
\hline Statement & Min & Max & Mean & \multicolumn{2}{|c|}{ Std. Dev. } & \multicolumn{2}{|c|}{ Variance } \\
\cline { 2 - 7 } & Stat. & Stat. & Statistic & Std. Error & Stat. & Stat. \\
\hline $\begin{array}{l}\text { Teachers are lowly motivated/ } \\
\text { dissatisfied with their jobs }\end{array}$ & 4 & 10 & 6.40 & 1.030 & 2.302 & 5.300 \\
\hline $\begin{array}{l}\text { The relationship between } \\
\text { teachers and their employer is } \\
\text { strained }\end{array}$ & 4 & 7 & 5.40 & .600 & 1.342 & 1.800 \\
\hline $\begin{array}{l}\text { Their seem to be a } \\
\text { misunderstanding by TSC on } \\
\text { Teachers grievances }\end{array}$ & 2 & 7 & 4.20 & .860 & 1.92 & $\begin{array}{l}3.70 \\
0\end{array}$ \\
\hline
\end{tabular}

When the respondents were asked to indicate the causes of conflicts between Teachers Service Commission and the teachers unions, they indicated as shown in the table above. Salary had (mean $=12$ and a standard deviation of 1.581), Working environment (mean = 8.00 and standard deviation of 2.236), Low motivation (mean $=6.40$ and standard deviation of 2.302), Strained relationships (mean $=5.40$ and standard deviation $=1.342$ ) and grievance misunderstanding (mean $=4.20$ and standard deviation $=1.924)$. The variances of the issues under-consideration as observed on the table are as follows; Salary (2.500), working environment (5.000), low motivation (5.300), strained relationships (1.800) and grievance understanding (3.700). Teachers in all public secondary schools agreed to many factors that cause disputes between teachers and their employer; Teachers Services Commission. Majority of the respondents indicated low salary to be the main cause; their complaints were based on the fact that, salaries and allowances did not match with other professionals with similar qualifications. The salaries had been set decades ago, but with time only allowances have been increased with a slight percentage. Given the current economic hardships in the country and more responsibilities they have to undertake, they justified the reason why it causes them to strike.

The other factor indicated to be a cause of strikes is lack of motivation by the employer. Respondents indicated that Teachers Service Commission does not recognize the sacrifices they make in delivering services in the schools. Despite the schools being within the city, they still face hardship which they have made the employer aware, however, little has been done. Furthermore, respondents indicated poor working environment in schools to be a reason as to why they also go on strike. Schools have poor infrastructures and facilities that can enable the teachers deliver as per the expectations of the society. Furthermore, strained relationship between the teachers union and the teachers' employer was indicated to cause conflicts between Kenya National Union of Teachers and Teachers Service Commission. It was indicated that, there is mistrust between the two bodies due to past agreements that TSC has failed to implement. When a dispute arises, KNUT found it appropriate to go on strike than sit at a table to renegotiate similar problems like in the past. Other factor observed was misunderstanding of issues raised by teachers to their employer. In agreement with the findings, Mugho (2017) established that poor remuneration, lack of adherence to collective bargaining agreement, delays in job group promotions and poor working conditions were the major causes of teachers' strikes in public schools in Kenya. Similarly, Onyango, (2012) in his study on the use of industrial action in resolving labor disputes among selected trade unions in the education sector found out that the major causes of industrial action were demands for better salary, welfare and failure to honor collective bargaining agreements by the employers. 


\subsection{Nature of Disputes between TSC and KNUT/KUPPET}

The second objective of the study was to investigate the nature of conflicts between TSC and KNUT/KUPPET. To achieve this objective, the study respondents were asked to indicate their level of agreement or disagreement on various aspects measuring nature of disputes between the TSC and the KNUT/KUPPET. The higher mean scores on the scale illustrated that most of the respondents agreed with the statements in the table while the lowest mean scores on the scale illustrated that majority of the respondents disagreed with the statements in the table. Presented in Table 2 are the results of the analysis.

Table 2: Natures of Disputes

\begin{tabular}{|l|l|l|l|l|l|l|}
\hline \multirow{2}{*}{ Statement } & \multicolumn{6}{|l|}{ Descriptive statistics } \\
\cline { 2 - 7 } & Min & Max & Mean & $\begin{array}{l}\text { Std. } \\
\text { Dev. }\end{array}$ & \multicolumn{2}{l|}{ Variance } \\
\cline { 2 - 8 } & Stat. & Stat. & Statistic & $\begin{array}{l}\text { Std. } \\
\text { Error }\end{array}$ & $\begin{array}{l}\text { Statisti } \\
\text { c }\end{array}$ & Statistic \\
\hline $\begin{array}{l}\text { Disputes always arise out of } \\
\text { disagreement and disrespect } \\
\text { of rights. }\end{array}$ & 10 & 17 & 12.60 & 1.208 & 2.702 & 7.300 \\
\hline $\begin{array}{l}\text { Disputes are manifested by } \\
\text { hostilities between workers }\end{array}$ & 5 & 13 & 9.60 & 1.327 & 2.966 & 8.800 \\
\hline $\begin{array}{l}\text { When disputes happen, } \\
\text { teachers go on strike. }\end{array}$ & 7 & 12 & 9.60 & .927 & 2.074 & 4.300 \\
\hline $\begin{array}{l}\text { Other industrial actions are } \\
\text { used when disputes happen } \\
\text { apart from strikes like } \\
\text { picketing, go slows etc. }\end{array}$ & 6 & 13 & 9.40 & 1.327 & 2.966 & 8.800 \\
\hline $\begin{array}{l}\text { Disputes can happen between } \\
\text { individuals or parties }\end{array}$ & 5 & 10 & 7.20 & .860 & 1.924 & 3.700 \\
\hline
\end{tabular}

When respondents were asked to indicate the nature of disputes they indicated as follows: Disagreement and disrespect of rights (Mean = 12.60, Std. Dev. 2.702), Hostilities between workers $($ Mean = 9.60, Std. Dev. 2.966), Strike $($ Mean = 9.60, Std. Dev =2.074), various industrial actions (Mean = 9.40, Std. Dev. 2.966), Individual and party (Mean = 7.20, Std. Dev. 1.924). The variances of the responses are as follows; Disagreement and disrespect of rights (7.300), Hostilities between workers (8.800), Strike (4.300), various industrial actions (8.00), Individual and party (3.700). Study findings show that disputes between teachers and their employer happen in various ways, however, disagreements and disrespect of teachers' rights were seen to be the main form of dispute as indicated by majority of the respondents. The disagreements happen due to the lack of Teachers Service Union not honoring earlier negotiated collective agreements. Furthermore, it was found that hostility between workers was another major form of disputes. This led to misunderstanding and poor co-operation, for instance, teachers in secondary schools fall under KUPPET and KNUT at some point conflict of affiliation due to stand taken by one union and opposed by the other union led to the hostilities. In addition, strike was also observed to be another major form of disputes as teachers down their tools when their grievances are not solved. Teachers also used other forms of industrial actions such as go slows, demonstrations in schools in order to make their demands known by the public and relevant authorities. In some instances, individual teachers used legal means to settle their disputes with the Teachers service Commission in consultation with teacher's trade union. 
In agreement with the findings, Longe (2015) established that the most common type of conflict was union-management conflict. Other types of workplace conflicts reported in the study included procedural conflict, job task-related conflict, interpersonal conflict and personal conflicts. In another study, Herzberg, (2003) established that workplace conflict takes many shapes and forms. It can be as overt as a strike by workers over an issue of concern or as covert as an individual dissatisfied with his or her job expressing anger or frustration through absenteeism, lower productivity or sabotage. Alternatively, an interpersonal dispute between two colleagues can manifest itself through refusal to work together, hostility or bullying. Zhou, Xi, Zhang and Zhao (2017) argued that the two dimensions - conflicts of interests and rights conflicts, are inadequate to explain the overall meaning of labor relations conflict. They proposed an additional dimension which they termed emotion-based conflicts. According to Zhou et al. (2017), emotion-based conflicts are caused by the employer's disrespect for employees and interpersonal conflicts between employers and employees. When the employer disrespects employees' human dignity, the fruits of their labor and the value of their labor and fails to establish harmonious interpersonal relations between employees and employers, emotion-based conflict may occur.

\subsection{Effects of Disputes on Quality of Education}

The third objective of the study was to examine the effect of labour disputes on quality of education in public secondary school within Mvita Constituency, Mombasa County. The researcher provided the study respondents with five statements of a 5-point likert scale. The higher mean scores on the scale illustrated that most of the respondents agreed with the statements in the table while the lowest mean scores on the scale illustrated that majority of the respondents disagreed with the statements in the table. Presented in Table 3 are the descriptive analysis results obtained.

Table 3: Disputes and Academic Performance

\begin{tabular}{|l|l|l|l|l|l|l|l|l|}
\hline Statement & $\begin{array}{l}\text { Mi } \\
\mathbf{n}\end{array}$ & Max & Mean & \multicolumn{2}{|l|}{$\begin{array}{l}\text { Std. } \\
\text { Dev. }\end{array}$} & \multicolumn{2}{|l|}{$\begin{array}{l}\text { Varia } \\
\text { nce }\end{array}$} & \multicolumn{2}{|l|}{ Kurtosis } \\
\cline { 2 - 9 } & St & Stat. & Stat. & $\begin{array}{l}\text { Std. } \\
\text { Error }\end{array}$ & Stat. & Stat. & Stat. & $\begin{array}{l}\text { Std } \\
\text { Err } \\
\text { or }\end{array}$ \\
\hline $\begin{array}{l}\text { Disputes lead to disruption of } \\
\text { school hours }\end{array}$ & 7 & 13 & 10.20 & 1.356 & 3.033 & 9.2 & 3.081 & 2 \\
\hline $\begin{array}{l}\text { Disputes make teachers less } \\
\text { motivated to work }\end{array}$ & 9 & 15 & 13.20 & 1.200 & 2.683 & 7.2 & .312 & 2 \\
\hline $\begin{array}{l}\text { When teachers strike, school } \\
\text { performance drops. }\end{array}$ & 5 & 11 & 8.20 & .970 & 2.168 & 4.7 & 1.435 & 2 \\
\hline $\begin{array}{l}\text { Disputes hinder syllabus } \\
\text { coverage }\end{array}$ & 7 & 15 & 9.40 & 1.503 & 3.362 & 11.3 & 2.316 & 2 \\
\hline $\begin{array}{l}\text { Disputes undermine } \\
\text { provision of quality } \\
\text { education }\end{array}$ & 6 & 11 & 7.80 & .860 & 1.924 & 3.7 & 2.608 & 2 \\
\hline
\end{tabular}

The study sought to establish the effect of disputes on quality of education in the schools within Mvita. As presented in Table 4.6 above, the respondents indicated that, disputes lead to; disruption of school hours $($ Mean $=10.20$, Std. dev. $=1.356)$, Less motivated teachers $($ mean $=13.20$, Std. dev. $=2.683)$, Drop of school performance $($ Mean $=8.20$, Std. dev. $=$ $2.168)$, Hindered syllabus coverage $($ Mean $=9.40$, Std. Dev $=3.362)$, Undermining provision 
of quality education (mean $=7.80$, Std. Dev $=1.924$ ). The variables had different variances as indicated in the findings; Disruption of school Hours (9.200), Less motivated teachers (7.200), Drop in school performance (4.700), Syllabus coverage (11.300) and education quality (3.700). Further, a kurtosis analysis indicated the following; Disruption of school Hours (-3.081), Less motivated teachers (0.312), Drop in school performance (1.345), Syllabus coverage (2.316) and education quality (2.60).

The findings show that the biggest effect of the disputes is demotivated teachers; this is caused by un-fulfilled demands by the employer. Teachers resume classes to teach with low motive and less drive because they have no choice after false promises are made by the government that go unfulfilled, in essence they go back to face the same challenges that made them strike. Furthermore, lost school hours were indicated to be the second effect that disputes had on schools due to the fact that both teachers and students stayed away from schools during the strikes. Save for some students who made arrangement for private tuition and spent time at the national library to compensate for the lost academic hours, many did not bother to study during the teachers' strike. Therefore, when strikes ended, there was hardly any time left to cover the syllabus and especially for those students who were sitting for their Kenya Certificate of Secondary Examinations. As a result, this led to students being rushed through the syllabus making students to spend more time in classes.

Respondents also indicated that, students dropped their performance when strikes happened when compared to other academic years when learning went on smoothly. This was caused by poor syllabus coverage and other factors as indicated earlier which hindered the provision of quality education. The effect on student's performance during conflicts was not uniform in all schools; it was dependent on the extra arrangements that each student or school had to cover for the lost time. It was evident however, that schools reported a decline in performance at that time of the conflict. Through interviews, the researcher noted that most of all the TSC and county administrators approved that labour disputes had a negative impact on academic performance. The interviewee reported that when teaching and learning processes were disrupted with strikes, teachers were unable to cover the syllabus which eventually leads to decline in performance among the students and the schools as a whole. The findings of the study relate to those of (Olukunle, 2011) who assessed strikes and students learning effectiveness in academic programs and (Isangedighi, 2007) and (Iheanacho, 2002) all conducted in Nigeria. Olukunle (2011) in his assessment of strike and students learning effectiveness in Nigeria asserts that disruption in academic program as caused by strike gives students undeserved study years extension. Isangedighi (2007) and Iheanacho (2002) agreed that effective learning is achieved when students are emotionally and psychologically stable. But on the contrary, when disruption in academic program occurs from strike action, students become emotionally and psychologically unstable especially on the perception that it will cause them to stay at school longer than expected.

\subsection{Regression Analysis}

The study variables were analyzed using a multiple regression method to establish the relationship between the independent variables and dependent variable of the study. The dependent variable is quality of education in public secondary schools while the independent variables include; conflicts between TSC and Teachers unions, effect of disputes on academic performance and nature of disputes. Inferential statistics analysis by use of the following equation, $Y=\beta_{0}+\beta_{1} X_{1}+\beta_{2} X_{2}+\beta_{3} X_{3}+\varepsilon$. Table 4 presents the model summary. 
Table 4: Model Summary

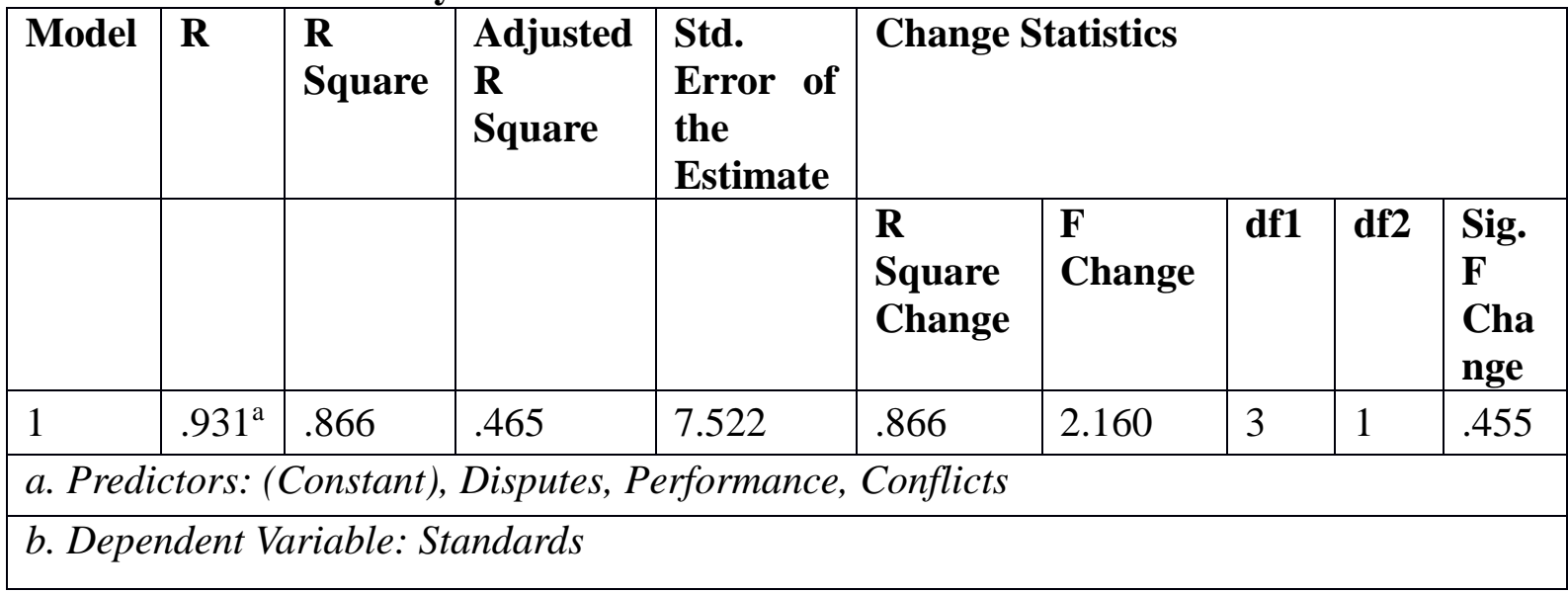

Table 4 indicates that the fitness of the model was adequate. This is proved by $\mathrm{R}^{2}$ of 0.866 which means that $86.6 \%$ of the variation of quality education is due to conflicts between TSC and Teachers unions, effect of disputes on academic performance and the nature of disputes. The correlation co-efficient of $93.1 \%$ shows that the dependent variables have a strong positive correlation with the quality of education in Mvita public secondary schools. It can be observed that, anytime there is a teachers strike then the quality of education is comprised. In line with the findings, Wills (2014) discovered that teacher strike participation negatively affected learning for students. Majority of the students who were more likely affected by the teachers strike included those who were weaker academically and those attending schools in rural areas. Another study by Ajewole (2014) found out that labour strike has a negative impact in attaining the objectives of the university education. These effects include disruption of academic calendar, financial losses, economic retardation, drop out, brain drain and educational wastage.

Table: 5: ANOVA analyses

\begin{tabular}{|c|c|c|c|c|c|c|}
\hline \multicolumn{7}{|c|}{ ANOVA } \\
\hline Model & Sum of Squares & df & Mean Square & $\mathbf{F}$ & Sig. & \\
\hline \multirow{3}{*}{1} & Regression & 366.624 & 3 & 122.208 & 2.160 & $.455^{\mathrm{b}}$ \\
\hline & Residual & 56.576 & 1 & 56.576 & & \\
\hline & Total & 423.200 & 4 & & & \\
\hline \multicolumn{7}{|c|}{ a. Dependent Variable: Standards } \\
\hline \multicolumn{7}{|c|}{ b. Predictors: (Constant), Disputes, Performance, Conflicts } \\
\hline
\end{tabular}

In Table 5 above the analysis of variance indicate that; the independent variables i.e. Disputes, nature of disputes and conflicts together are not statistical significant in explaining the quality of education in public value demonstrated by a $\mathrm{P}$ value $(0.455)$ which is greater than the accepted critical $\mathrm{p}$ value of 0.05 but positively related.

Table 6: Regression Co-efficient

\begin{tabular}{|c|c|c|c|c|c|}
\hline Unstandardized & Standardized & $\mathbf{t}$ & \multirow[t]{2}{*}{ Sig. } & \multicolumn{2}{|c|}{ 95.0\% Confidence Interval for B } \\
\hline B & Std. Error & Beta & & $\begin{array}{l}\text { Lower } \\
\text { Boun } \\
\text { d }\end{array}$ & Upper Bound \\
\hline
\end{tabular}


International Journal of Current Aspects, Volume 3, Issue II, 2019, PP 243-259, ISSN 2616-6976 [IJCAB

\begin{tabular}{|l|l|l|l|l|l|l|l|}
\hline (Constant) & -87.533 & $\begin{array}{l}69.25 \\
2\end{array}$ & & -1.264 & .426 & -967.458 & 792.391 \\
\hline Conflicts & 2.479 & 3.529 & .381 & .703 & .610 & -42.359 & 47.318 \\
\hline Performance & 1.008 & 1.815 & .297 & .555 & .677 & -22.049 & 24.065 \\
\hline Disputes & 6.341 & 2.537 & .935 & 2.500 & .242 & -25.893 & 38.576 \\
\hline \multicolumn{7}{|l}{ a. Dependent Variable: Standards } \\
\hline
\end{tabular}

As shown in Table 6, the study variables indicated varied $\mathrm{p}$ values i.e. conflict $(0.610)$, Performance (0.677) and disputes (0.242). The beta Co-efficient for the variables are indicated as follows; conflicts (0.381), performance (0.297) and disputes (0.933). The $p$ values of the variables are all greater than the accepted critical value of 0.05 which means that they are statistically insignificant to the quality of education however they have a positive relationship. In agreement with the study findings, Ohiwerei and Onimawo (2016) established that strike has played negative effect in the academic achievement of students in most learning institutions. This is because during the strikes students get involved in behaviours which make them loose academic interest hence leading to poor performance and decline in the quality of education. Similarly, a study by Akintoye \& Uhunmwuangho (2018) found out that frequent strikes had adverse effects on the academic performance of students and the schools as a whole.

\section{CONCLUSIONS}

The main goal of the study was to find out the effects of labor disputes on the quality of education in public secondary schools in Mvita Constituency, Mombasa County. From the study findings presented above, the study concludes that there are conflicting interests between Teachers Service Commission and Teachers Unions. Major causes of these conflicts are salaries, poor working environment, low motivation for teachers, mishandling of teachers grievances and promotions. The study concludes that; disputes affect school performances because at such times teachers stay away from schools and students stay at home. This leads to poor coverage of the syllabus, when schools open the workload is so high that teachers cannot cover everything forcing students sit for examination without learning some subjects. The study concludes that; disputes in schools take various forms such as strikes, confrontations on teacher's rights, picketing and go-slows. When a solution is not found through collective agreement, teacher's desert schools which end up closed until the disputes are resolved. The study concludes that; conflicts, disruption of school hours and strikes moderately affect the quality of education. The relationship observed is positively strong although statistically insignificant, it cannot be ignored.

\section{RECOMMENDATIONS}

Teacher's service commission needs to hold a consultative meeting with all stakeholders to understand the issues affecting schools. Through this, they will get a comprehensive understanding of the reasons why quality of education in public secondary schools has been compromised hence develop policies that address all the aspects of the education system and not demand good performance from teachers yet the working environment is hindering them from giving their best. Teachers Service Commission and the Teachers Unions should make consultations a continuous process so that they deal with grievances as they happen. Both parties should cease the habit of addressing issues only when they are out of control. In these negotiations, teachers unions should consult the teachers on what their grievances are and negotiate on a wide range of issues that will address basically causes of disputes in public 
secondary schools and not only calling for increment of salaries and allowances. There is need for the negotiated collective bargaining to be implemented as agreed between the parties as failure to do so, is one of the major causes of labour disputes. In cases where the Teachers Service Commission and the government cannot meet the terms of the agreement, a framework should be adopted that will stipulate the implementation process and evaluation of the same done by both parties. There is need to adopt the world best education policies that will improve the education sector by ensuring that; qualified and adequate teachers are recruited, teachers' pay match their work, schools are equipped with the right resources so that the students are not entirely dependent on the teachers but can learn on their own and complement what is taught in class. This will result to improvement of quality of education in public secondary schools.

\section{REFERENCES}

Addison, J. T. \& Teixeira, V. (2009). Are Good Industrial Relations Good for the Economy? German Economic Review, Berlin.

Adler, N. J. (2008). International Dimensions of Organizational Behavior, $5^{\text {th }}$ Edition, Mason, Thomson Southern Western.

Ajewole, I.P. (2014). Managing Labour Unrest in Nigerian Universities. Journal of Education and Leadership Development. Vol. 6(2); 93-107.

Akintoye, E. O. \& Uhunmwuangho, S. O. (2018). Analysis of the Effects of Frequent Strikes on Academic Performance of Students in Universities in Nigeria: Edo State as a Focal Point, International Multi-Disciplinary Journal, Vol. 12 (1); 56-65.

Alan, P. (2007). Human Resource Management in a Business Context. 3rd Edition, Seng Lee Press. Singapore.

Armstrong, M. (2009). A handbook of Personnel Management Practice, $10^{\text {th }}$ Edition, Kogan Page Limited, London.

Armstrong, M. (2009). Armstrong's handbook of human resource management practice, London: Kogan, Page.

Baker, M. (2013). Industrial actions in schools: strikes and student achievement, Canadian Journal of Economics, 46(3); 1014-1036.

Beardwell, J. \& Claydon T., (2007). Human Resource Management: A Contemporary Approach. Pearson Education, Harlow.

Briscoe, D. R. \& Schuler, R. S. (2004). International Human Resource Management, 2nd edition, Routledge, London.

Browarys, M. \& Price R. (2008). Understanding Cross Cultural Management, Pearson Education, Harlow.

Centola, D. \& Macy M. (2007). Complex Contagion and the Weakness of Long Ties, American Journal of Sociology.

Chiappe M. (2011). La conflictividad laboral entre los docents publicos argentines 20062010 (Buenos Aires: Direccion de Estudios de Relaciones del Trabajo)

Cole, G. A. (2007). Personnel and human resource Management, 5th Edition, Thomson Learning High Holborn House 50-51 Benford Row, London

Confederación de Educadores Argentinos (2009). Historia del movimiento obrero y delsindicalismo en Argentina" (Mimeo: Confederación de Educadores Argentinos Buenos Aires)

Dahida, D.P. \& Adekeye, J. A. (2013). A Comparative Analysis of Trade Disputes Settlement in Nigerian Public and Private University. Journal of Law, Policy and Globalization, 18 (1), 60-68.

Fryer, R.G. (2011). Teacher Incentives and Student Achievement: Evidence from New York City Public Schools, Harvard University and NBER. 
Gathoronjo, S. (2008). A study on the perception of the ministry of labour on the causes of labour disputes in the public sector. Unpublished MBA Thesis, Nairobi University, Kenya.

Herzberg, F. (2003). One more time: How do you motivate employees? Harvard Business Review, 5(1); 86-96. Retrieved from http://hbr.org/.

Ibrahim, I. (2007). Kenya: Educator's union tackling the teacher de-professionalization issue. Educational International, Vol. 13; 121-139.

Ige, T. (2013). Effects of Labor Strikes on the Quality of University Education in Nigeria. Unpublished PhD Thesis, Walden University, Nigeria.

Iheanacho, R. A. (2002). Psychology of learning. Owerri: GOC International Publishers.

ILO (2004). Organizing for Social Justice: Global Report under the Follow-up to the ILO Declaration on Fundamental Principles and Rights at Work, Report of the DirectorGeneral, Geneva.

ILO (2011). Promoting jobs, protecting people http: accessed via //www.ilo.org/legacy/english/dialogue at 18/9/2018

Institute of Economic Affairs (2002). Crisis in the education sector: Education policy and financing, the budget focus, a publication of the IEA Budget information programme. New York.

Isa, A. A. (2015). Conflicts in Organizations: Causes and Consequences. Journal of Educational Policy and Entrepreneurial Research, 2 (11); 54-59.

Isangedighi, A. J. (2007). Child psychology, education and development, Calabar: Eti-Nwa Edition, Singapore

Jones, S.M. \& Bouffard, S.M. (2012). Social and emotional learning in schools: From programs to strategies, Social Policy Report, England.

Juma F. (2011). The relationship between mode of Teacher Motivation and Students Academic Performance in public secondary schools in Bungoma North District (Unpublished M.E.D Project Report), Moi University Kenya Working Paper 12155. Cambridge, MA: National Bureau of Economic Research.

Kagolo, F. (2014). School inspectors: where did they go, The New vision, Uganda

Kibe, J. W. (2014). Factors affecting settlement of industrial disputes by the Kenya National Union of Teachers (KNUT). Unpublished MEd Thesis, University of Nairobi.

Kingdom, G. \& Teal, F. (2010). Teacher unions, teacher pay and student performance in India: A pupil fixed effects approach, Journal of Development Economics, vol. 91, pp. 278-288.

Kitunga, S.M. (2009). Benefits of Kenya National union of Teachers' welfare programmes to primary school teachers in Mwingi district, Kenya (unpublished Masters Dissertation) Kenyatta University.

Klandermans, B. (1984). Mobilization and Participation: Social Psychological Expansions of Resource Mobilization Theory', American Sociological Review, New York.

Kothari, R.C. (2004). Research Methodology: Methods and Techniques, 2nd ed. Delhi: New Age International.

Longe, O. (2015). Impact of workplace conflict management on organizational performance: A case of Nigerian manufacturing firm. Journal of Management and Strategy, 6(2): 83-92.

Lumuli, N.C. (2009). An Investigation into internal Efficiency Measures in Promotion of Access and Completion Rates in Public Secondary in Bungoma South District (Unpublished M. Ed Thesis), University of Nairobi.

Ministry of Education (2008). Report on School Unrest, Government Press, Nairobi

MoE (2010). The development of education: national report of Kenya, Report presented at the International Conference on Education, Geneva 
Moulton, G. J. (2011). Great Depression of Wages: An Investigation of the Impact of Entering the Labor Market during the Great Depression using a Regression Discontinuity Approach, working paper.

Mugenda, O. M. \& Mugenda, A. G. (2006). Research methods: Qualitative and Quantitative Approaches. Nairobi: Acts Press.

Mugenda, O.M. \& Mugenda, A. G. (2006). Research methods; quantitative and qualitative Approaches. Nairobi; Acts press.

Mugho, S. M. (2017). Causes of the recent teachers strikes in Kenya. Journal of Public Policy and Administration, 2 (2); 28- 42.

Murthy, R. P. (2006). Management Science and Industrial Management. Pragon International Publishers, New Delhi.

Nabibya, C. J. (2013). Influence of Kenya National Union of Teachers on teacher's performance in public primary schools in Kamukunji District, Nairobi County, Kenya. Unpublished Med Thesis, Nairobi University Kenya.

Ndlovu, S. Phiri, K. \& Mutale, S. B. (2014). The effects of teacher incentives on education in Bulawayo, European Journal of Academic Research, Vol. 2, Zimbabwe.

Ohiwerei, F. O. \& Onimawo, J. A. (2016). Effects of Strike on the Academic Performance of Business Education Students in Nigerian Universities. International Journal of Academic Research in Progressive Education and Development, 5(3); 77-85.

Ohiwerei, F. O. \& Onimawo, J.A. (2016). Effects of strike on the academic performance of business education students in Nigerian Universities. International Journal of Academic Research in Progressive Education and Development, Vol. 5 (3): 77-85.

Olukunle, O. (2011). The strike and student learning effectiveness, a paper presentation in Lagos.

Onyango, O. (2012). A survey of perception of members of the use of industrial action in resolving labour disputes among selected trade unions in the education sector in Kisumu County. Unpublished Thesis, University of Nairobi.

Oso, W.Y \& Onen, D. (2009). A general guide to writing research proposals and reports, The Jomo Kenyatta Foundation, Nairobi.

Picho, E.O. (2014). The relationship between employee reward and job satisfaction in Uganda management institute: an empirical study. The Ugandan Journal of Management and Public Policy Studies, 7 (1); 1-20.

Republic of Kenya (2008). Kenya Education Sector Support Programme 2005 - 2010: Delivering quality education and training to all Kenyans, Ministry of Education Science and Technology, Slavin LS, Economics, Richard DI Publishers.

Rose, P. (2007). The Education Fast Track Initiative: A Global Campaign review of progress, and recommendations for reform, Action Aid and the Global Campaign for Education, United Kingdom.

Tanzania Teachers Union (2011). Education for All: Teacher Demand and Supply Education International Working Papers no 12, University Press.

UNESCO (2002). Education for All: Global Monitoring Report. Is the World on Track? Paris, France.

USAID, (2009). Review of basic education quality in Ghana, basic education in Ghana: progress and problems, final report, the Michell Group.

Wills, G., (2014). Effects of teacher strike activity on student learning in South African primary schools, a working paper of the Department of Economics and Bureau of Economic Research at the University of Stelleinbosch.

World Bank (2006). Schooling Access to Learning Outcomes: An Unfinished Agenda: An Evaluation of World Bank Support to Primary Education. Independent Evaluation Group, World Bank. 
World Bank (2006). World Development Report: Development and the Next Generation. Washington, D.C.: World Bank.

Zakari, Y. H. (2018). The Causes and Effects of Industrial Disputes by the Academic Staff Union of Colleges of Education: A Case Study of Federal College of Education, Zaria. International Journal of Research and Innovation in Social Science, Vol. 2(1); 1-7.

Zhou, L., Xi, M., Zhang, X. \& Zhao, S. (2017). Labor relations conflict in the workplace: Scale development, consequences and solutions. Paper presented at Conflict and its Resolution in the Changing World of Work: A Conference and Special Issue Honoring

David B. Lipsky, Ithaca, NY. Available online at: http://digitalcommons.ilr.cornell.edu/lipskycrconference/12

This is an open-access article published and distributed under the terms and conditions of the $(\mathrm{ccc}) \mathrm{EY}$ Creative Commons Attribution 4.0 International License of United States unless otherwise stated. Access, citation and distribution of this article is allowed with full recognition of the authors and the source.

Authors seeking to publish with an International Peer Reviewed Journal should consider www.ijcab.org by writing to the Editor at editor@ijcab.org. List of our Journals are Available at www.ijcab.org/journals 